\title{
MINUMAN BERBAHAN DASAR KEDELAI SEBAGAI ANTIHIPERTENSI
}

\author{
Binti Maulina Putri, Yasinta Nofia \\ 1Pascasarjana Prodi Ilmu Gizi, Universitas Sebelas Maret, Surakarta, Jawa Tengah, Indonesia \\ Jalan antariksa no 6 kost mirah kecamatan Jebres Surakarta (domisili sementara studi) \\ Korespondensi email: bintim0607@student.uns.ac.id
}

Submitted: 01 Oktober 2019, Revised: 20 Januari 2020, Accepted: 10 April 2020

\begin{abstract}
Hypertension is a degenerative disease that can affect all age groups. Management of hypertension can be done using non-pharmacological therapy by managing blood pressure, controlling risk factors and controlling other diseases. One of the non-pharmacological treatment is by controlling food intake by using functional food. Functional food that can be used to treat hypertension is soy. Soybean (Glycine Max) is a type of bean that has potential as a functional food that contains bioactive substances such as isoflavones, saponins, lecithin, proteins and phytosterols which can reduce the risk of cardiovascular disease. The purpose of this review literature is to describe the mechanism of bioactive compounds that act as antihypertensive agents in soybeans. The method in this research is through searching data sourced from Google Scholar with the keywords soybeans drink, hypertension, bioactive compounds from 2017-2019 obtained 706 journals. Then with the inclusion criteria in the form of the content and mechanism of protein, isoflavones, and potassium 14 journals were obtained. Data analysis was performed descriptively. The results of this review literature suggest that the administration of soy-based drinks can reduce blood pressure (potential vasodepressor, precursors for vasodepressor of nitric oxide (NO) and increase $\mathrm{Na}$ and $\mathrm{K}$ secretion in urine) with the right formulation and amount. The content of proteins (amino acids arginine, tryptophan), isoflavones as antioxidants, and potassium in soybeans can reduce blood pressure in people with hypertension. Drinks from soybeans namely soy milk and soybean fermented drinks namely tempe extract drinks can be used as a non-pharmacological therapy for patients with hypertension or as a a step to prevent hypertension.
\end{abstract}

Keyword: hypertension, blood pressure, soybeans

\begin{abstract}
Abstrak
Hipertensi merupakan salah satu penyakit degeneratif yang dapat menyerang semua golongan usia. Penatalaksaan penyakit hipertensi dapat dilakukan menggunakan terapi non-farmakologi dengan cara mengelola tekanan darah, melakukan pengendalian faktor resiko dan pengendalian penyakit lainnya. Salah satu pengobatan non-farmakologi dengan cara pengontrolan asupan makan dengan pemanfaatan pangan fungsional. Pangan fungsional yang dapat digunakan untuk mengatasi hipertensi adalah kedelai. Kedelai (Glycine Max) merupakan salah satu jenis kacang yang memiliki potensi sebagai pangan fungsional yang mengandung zat bioaktif seperti isoflavon, saponin, lesitin, protein dan fitosterol yang dapat menurunkan risiko penyakit kardiovaskular. Tujuan dari literature review ini adalah menggambarkan mekanisme senyawa bioaktif yang berperan sebagai zat antihipertensi dalam kacang kedelai. Metode dalam penelitian ini melalui pencarian data bersumber dari google scholar dengan kata kunci soybeans drink, hipertensi, senyawa bioaktif dari tahun 2017-2019 didapat 706 jurnal. Kemudian dengan kriteria inklusi berupa kandungan dan mekanisme protein, isoflavon, dan kalium didapatkan 14 jurnal. Analisis data dilakukan secara deskriptif. Hasil literature review ini bahwa pemberian minuman bahan dasar kacang kedelai mampu menurunkan tekanan darah (vasodepresor yang potensial, prekursor untuk vasodepresor nitric axide (NO) serta menigkatkan sekresi $\mathrm{Na}$ dan $\mathrm{K}$ dalam urin) dengan formulasi dan jumlah yang tepat. Kandungan protein (asam amino arginin, triptofan), isoflavon sebagai antioksidan, dan kalium dalam kacang kedelai dapat menurunkan tekanan darah pada penderita hipertensi. Minuman dari kacang kedelai yaitu susu kedelai dan minuman dari hasil fermentasi kacang kedelai yaitu minuman ekstrak tempe dapat dijadikan terapi nonfarmakologi bagi penderita hipertensi maupun sebagai langkah untuk mencegah terjadinya penyakit hipertensi.
\end{abstract}

Kata Kunci: hipertensi, tekanan darah, kacang kedelai

\section{Pendahuluan}

Hipertensi merupakan salah satu penyakit degeneratif yang dapat menyerang seluruh kelompok usia. Sebanyak 90\% penderita hipertensi belum diketahui penyebabnya secara pasti (1). Hipertensi sebagai "Silent Killer’ (Pembunuh Siluman), karena penyebab hipertensi seringkali tidak diketahui oleh para penderita 
hipertensi namun dirasakan suatu gangguan/gejalanya (1). Orang yang hipertensi berpotensi terserang penyakit lain seperti stroke dan penyakit jantung (2). Menurut WHO (World Health Organization) hipertensi menyerang 22\% penduduk di dunia. Hipertensi yang terjadi di Asia Tenggara mencapai 36\%. Di Indonesia berdasarkan hasil Riskesdas 2018 prevalensi kejadian hipertensi berusia 18 tahun ke atas sebesar 34,1\% (3).

Hipertensi dapat diatasi dengan terapi farmakologi dan nonfarmakologi (4). Terapi farmakologi hanya berdampak menurunkan tekanan darah sedangkan terapi nonfarmakologi bertujuan menurunkan tekanan darah serta mengendalikan faktor risiko dan penyakit lainnya. Terapi non-farmakologi dapat dilakukan dengan cara menghentikan kebiasaan merokok, menurunkan berat badan bagi orang yang memiliki berat badan berlebih, menghindari konsumsi alkohol, melakukan banyak kegiatan aktivitas fisik, menghindari asupan garam yang berlebihan, meningkatkan konsumsi buah dan sayur serta menghindari asupan lemak yang berlebihan (5).

Pengobatan penyakit hipertensi perlu didukung dari pengontrolan asupan makan, seperti dengan pemberian pangan fungsional. Kedelai (Glycine Max) merupakan salah satu jenis pangan fungsional yang mengandung zat bioaktif seperti isoflavon, saponin, lesitin, protein dan fitosterol yang dapat menurunkan risiko penyakit kardiovaskular (6). Di Indonesia, sekitar 83,7\% kedelai digunakan sebagai bahan pangan, terutama dalam bentuk tempe dan tahu dengan tingkat konsumsi 14,13 kg/kapita/tahun, 14,7\% untuk kecap dan tauco, sisanya untuk susu kedelai, kecambah, dan lain-lain (7).

Salah satu olahan makanan berbahan dasar kacang kedelai yang telah terbukti dapat menurunkan tekanan darah dan meningkatkan sekresi $\mathrm{Na}$ dan $\mathrm{K}$ melalui urin pada penderita pra-hipertensi (6) dalam bentuk minuman yaitu susu kedelai (8) dan minuman dari hasil fermentasi kacang kedelai yaitu minuman ekstrak tempe (serbuk) yang siap seduh bersifat inovatif, lebih praktis, mudah dikonsumsi dan lebih tahan lama (9).

Kurangnya pengetahuan kalangan masyarakat dengan manfaat susu kedelai bagi penderita hipertensi dan adanya pengembangan produk olahan minuman berbahan dasar kedelai dari ekstrak tempe menjadi alasan peneliti untuk melakukan penelitian tinjauan literatur (literature review) untuk mengkaji kandungan gizi dan zat bioaktif yang berperan sebagai zat antihipertensi dari minuman berbahan dasar kedelai

\section{Metode Penelitian}

Penelitian ini merupakan suatu tinjauan literature (literature review) dengan metode naratif yang mencoba menggali hasil penelitian di Indonesia terkait senyawa bioaktif yang bersifat sebagai zat antihipertensi. Sumber pencarian data bersumber dari google scholar dengan kata kunci soybeans drink, hipertensi, senyawa bioaktif dari tahun 2017-2019. Kemudian dengan kriteria inklusi berupa kandungan dan mekanisme protein, isoflavon, dan kalium, dan kacang kedelai, sehingga diperoleh 14 jurnal. Selain itu, terdapat beberapa jurnal atau artikel yang mendukung pembahasan penelitian ini

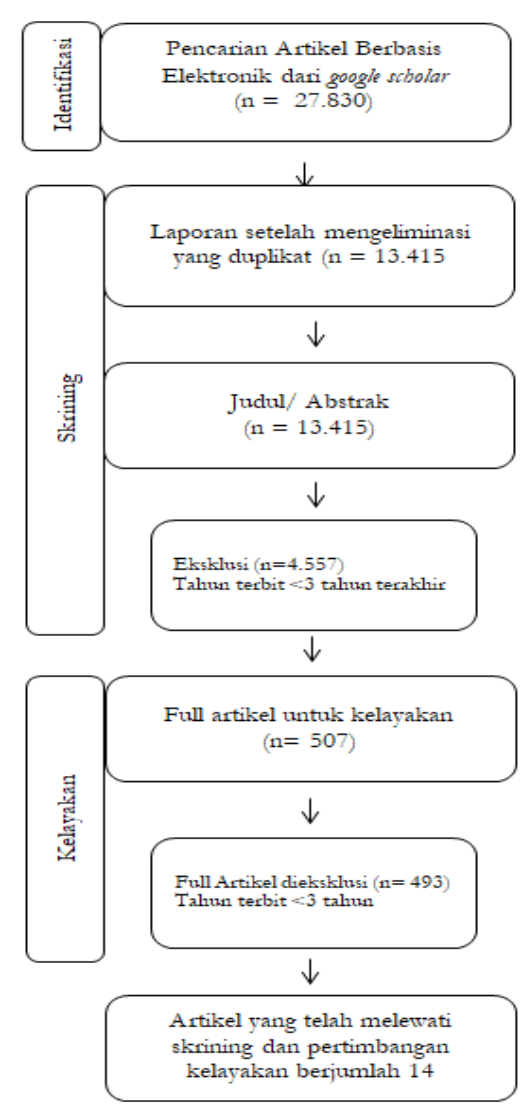

Gambar 1. Alur Penelitian 


\section{Hasil Dan Pembahasan}

Kacang kedelai mengandung zat bioaktif yaitu protein (asam amino arginin dan triptofan), isoflavon sebagai antioksidan, dan kalium yang dapat berperan sebagai antihipertensi.

\section{a. Protein (Asam Amino Arginin dan Triptofan)}

Salah satu hasil olahan dari kacang kedelai yaitu susu kedelai yang kaya akan zat gizi seperti protein, rendah lemak, sumber kalium serta mengandung isoflavon (6). Protein pada kedelai diperkirakan dapat memperbaiki tekanan darah dikarenakan kaya akan arginin, vasodepresor yang potensial dan prekursor untuk vasodepresor nitric oxide (NO)(6). Kandungan protein pada kacang kedelai lebih tinggi yaitu 35-38\% dibandingkan dengan kacang-kacangan lainnya dengan kadar proteinnya berkisar antara 20-30\%. Protein pada produk olahan kedelai bervariasi, misalnya tepung kedelai $50 \%$, konsentrat protein kedelai $70 \%$, dan isolat protein kedelai $90 \%(10)$.

Penurunan tekanan darah sistolik yang terjadi diduga karena adanya protein kedelai yang mengandung asam amino arginin yang merupakan prekursor untuk nitric oxide (NO) yang memiliki efek vasodilator. Nitric oxide memiliki sifat menghambat agregasi (penggumpalan) platelet darah sehingga dapat melancarkan sirkulasi darah (9). Beberapa penelitian menunjukkan kedelai memiliki efek positif terhadap tekanan darah pada penderita hipertensi (9).

Hasil penelitian Handayani et al. (2017) menunjukkan adanya perbedaan tekanan darah sebelum dan sesudah intervensi pada kelompok perlakuan diberikan susu kedelai sebanyak 2x250 cc selama 2 hari pada penderita hipertensi di RS Islam Jakarta Pondok Kopi. Pada kelompok perlakuan terjadi penurunan tekanan darah sistolik sebesar 15,5 $\mathrm{mmHg}$ dan diastolic $10,6 \mathrm{mmHg}$. Selisih penurunan tekanan darah pada kelompok perlakuan 2 kali lebih besar dibandingkan dengan selisih penurunan pada kelompok kontrol (sistolik 7,6 $\mathrm{mmHg}$ dan diastolik 3,5 $\mathrm{mmHg}$ ). Selain itu, penelitian yang sama pun dilakukan oleh Murti (2018) terdapat pengaruh positif yaitu perubahan tekanan darah lansia dengan hipertensi jika diberikan susu kedelai sebanyak 2 gelas perhari yang dilakukan pada 11 responden selama 5 hari berturut-turut. Selisih yang didapatkan pada sistolik mengalami penurunan sebesar $16,4 \mathrm{mmHg}$ dan selisih diastolik didapatkan penurunan $8,2 \mathrm{mmHg}(8)$.

Kedelai mengandung asam amino Triptofan yang merupakan produk awal dari melatonin yang menjadikan otot-otot tegang menjadi rileks. Pada penelitian Murti (2018) yang memberikan susu kedelai sebagai kelompok perlakuan, responden mengatakan lebih relaks dan tidur menjadi lebih nyenyak. Asam amino triptofan menghasilkan serotonin pada system syaraf pusat. Kadar serotonin plasma dan pergantian serotonin yang meningkat dapat menurunkan tekanan darah (8).

Tempe juga memiliki beberapa kelebihan dibandingkan dengan kedelai yaitu memiliki daya cerna protein, karbohidrat, dan lemak yang lebih baik, kandungan vitamin yang lebih tinggi, serta bioavailibilitas mineral yang lebih baik. Perlakuan perkecambahan yang dilakukan dapat meningkatkan kadar protein (9). Proses fermentasi oleh R. oligosporus yang terjadi pada proses pengolahan kedelai menjadi tempe mampu menghidrolisis protein dan beberapa senyawa kompleks lainnya menjadi bentuk yang lebih sederhana seperti asam amino dan peptida (9).

Hasil penelisian Ansarullah dkk (2018) menunjukkan perbedaan signifikan efek intervensi minuman tempe dari kedelai Grobogan (lokal) dan kedelai GMO impor yang tidak yang dikecambahkan dengan kelompok kontrol pada tekanan darah sistolik. Sebanyak 3 gelas/hari dengan setiap gelas berisi 35 gr serbuk yang diformulasikan. Pada tekanan diastolik tidak terdapat perbedaan yang signifikan tetapi cenderung mengalami penurunan

\section{b. Isoflavon sebagai antioksidan}

Isoflavon merupakan senyawa bioaktif yang memiliki aktivitas biologi seperti estrogen, sehingga seringkali disebut sebagai fitoestrogen. Sumber antioksidan yaitu antioksidan sintetik (hasil sintesis reaksi kimia) dan antioksidan alami (bahan alami yang diektraksi dari senyawa fenolik dari golongan flavonoid). Flavonoid yaitu metabolit sekunder berasal dari tanaman yang berperan dalam menangkal radikal bebas (7).

Kedelai mengandung isoflavon yang merupakan fitoestrogen yang secara struktural mirip dengan estrogen yang diduga menunjukkan aktivitas antihipertensi melalui peningkatan NO dan menurunkan angiotensin serta menghambat terbentuknya reaksi radikal bebas. Daidzein, glisitein, dan genistein merupakan jenis-jenis dari isoflavon. (9). Kandungan isoflavon pada biji kedelai bervariasi antara 128 hingga $380 \mathrm{mg} / 100$ $\mathrm{g}$ dan antara 80,7 hingga 213,6 mg/100g (7), bergantung varietas/genotype kedelai, lingkungan dan kondisi lingkungan tumbuh tanaman, budi daya, dan penanganan pascapanennya (7). Kandungan isoflavon dalam bentuk makanan berbeda dengan kandungan awalnya pada biji karena pengaruh proses pengolahan, seperti fermentasi meningkatkan kandungan isoflavon, pemanasan menurunkan isoflavon (11). 
Jenis isoflavon yang terkandung di dalam kacang kedelai berjumlah 12 jenis yang berikatan dengan molekul gula dalam bentuk glikosida dan tidak berikatan dengan molekul gula dalam bentuk aglikon. Daidzein dengan tiga glikosida konjugasinya (daidzin, asetildaidzin, dan malonildaidzin), genistein dengan tiga glikosida konjugasinya (genistin, asetilgenistin, dan malonilgenistin), dan glisitein dengan tiga glikosida konjugasinya (glisitin, asetiglisitin, dan malonilglisitin) (7).

Bentuk glikosida dalam kacang kedelai yaitu genistin, daidzin, dan glisitin (Gambar 1) kemudian menjadi senyawa aglikon apabila terfermentasi atau dalam bentuk produk olahan yang dicerna dalam usus halus manusia, kemudian dihidrolisis oleh enzim-glukosidase. Isoflavon dalam bentuk aglikon disebut genistein (5,7,4-trihidroksiisoflavon), daidzein (7,4- dihidroksiisoflavon), dan glisitein (7,4 dihidroksi-6metoksiisoflavon) sebagai isoflavonoid. Isoflavon yang lebih mudah diserap oleh usus halus dalam bentuk aglikon dan memiliki aktivitas antioksidan yang lebih tinggi. Komponen mayor dalam isoflavon dalam kelompok genistein sebesar 60\% dan daidzein sebesar 30\% dengan bentuk bebas maupun yang terkonjugasi. Sedangkan komponen minor dari kelompok glisitein sebesar 10\% dari total isoflavon kacang kedelai (11). Terdapat 3,5 mg isoflavon per gram protein (setara dengan berat aglikon) dalam satu porsi makanan tradisional berbahan baku kedelai (7).

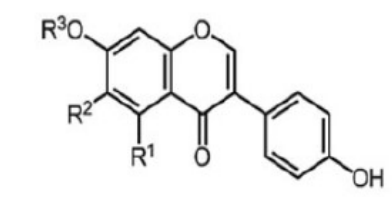

\begin{tabular}{lccc}
\hline & $\mathrm{R}^{1}$ & $\mathrm{R}^{2}$ & $\mathrm{R}^{3}$ \\
\hline Daidzin (1) & $\mathrm{H}$ & $\mathrm{H}$ & $\mathrm{Gle}$ \\
Glycitin (2) & $\mathrm{H}$ & $\mathrm{OCH}_{3}$ & $\mathrm{Gle}$ \\
Genistin (3) & $\mathrm{OH}$ & $\mathrm{H}$ & $\mathrm{Gle}$
\end{tabular}

Gambar 1. Struktur kimia isoflavon pada biji kedelai. Sumber: Oshima et al. (2016).

Tingkat konsumsi protein kedelai $25 \mathrm{~g}$ per hari atau setara dengan asupan isoflavon 37-62 mg, dinyatakan telah memenuhi $83 \%$ kebutuhan isoflavon harian yang dianjurkan (7). Kebutuhan tubuh manusia terhadap asupan isoflavon berbeda-beda tergantung berat badan, yakni $0,44 \mathrm{mg} / \mathrm{kg}$ berat badan per hari. Jika isoflavon dikonsumsi minimal $35 \mathrm{mg} /$ hari atau kira-kira sama dengan tiga potong tempe ukuran sedang, akan nyata perannya dalam menurunkan kadar lipid darah (7). Negara di kawasan Asia sebagian besar mengkonsumsi isoflavon 25-45 mg/hari, dan Jepang menunjukkan angka tertinggi sebesar $200 \mathrm{mg} / \mathrm{hari}$, sedangkan di negara-negara barat konsumsinya kurang dari $5 \mathrm{mg} /$ hari (7).

Perbandingan kadar isoflavon tempe lebih tinggi daripada biji kedelai. Kacang kedelai pada awal proses pemanasan pembuatan tempe memudahkan enzim glukosidase untuk tumbuh dan mengubah isoflavon terikat (glikosida) menjadi isoflavon tidak terikat (aglikon) pada saat proses fermentasi. Sehingga aglikon merupakan komponen isoflavon yang lebih banyak yang terkandung dalam tempe. Dalam bentuk aglikon, isoflavon lebih mudah terabsorbsi dibandingkan dalam bentuk glikosida (7).

Glikosida menurun secara signifikan selama fermentasi kedelai menjadi tempe oleh Aspergillus oryzae sedangkan jumlah aglikon tidak menunjukkan kecenderungan peningkatan yang stabil. Proses selanjutnya pengolahan tempe segar menjadi makanan siap santap juga berpengaruh terhadap kandungan isoflavon. Tingkat kehilangan isoflavon pada tempe yang dikukus sebesar 13,3\% lebih kecil dibandingkan dengan direbus $(18,2 \%)$ atau digoreng $(39,15 \%)$ (7). Pengaruh panas seperti merebus dan mengukus telah meningkatkan aglikon dan -glukosida isoflavon, tetapi menurunkan malonilglikosida (7).

Rasa langu pada susu kedelai yang tidak diinginkan karena senyawa volatil seperti aldehid yang disebabkan oleh tingginya oligosakarida dapat diatasi dengan fermentasi. Fermentasi juga meningkatkan nilai fungsional susu kedelai karena penggunaan mikroorganisme yang memiliki aktivitas -glukosidase, terutama bakteri asam laktat dan bifidobacteria menyebabkan biotransformasi isoflavon glikosida menjadi aglikon. Susu kedelai yang difermentasi dengan bakteri Lactobacillus acidophilus menunjukkan peningkatan daidzein sebesar 45,8\% dan genistein sebesar 57,5\% dari susu kedelai tanpa fermentasi (7).

Efek kardiovaskuler protektif dari quercetin telah menjadi fokus beberapa penelitian akhir-akhir ini khususnya penelitian mengenai efek senyawa flanol sebagai anti hipertensi. Senyawa flanol menghasilkan potensi untuk mengurangi stres oksidatif, menghambat aktifitas ACE dan meningkatkan relaksasi endotel pembuluh darah, mengatur signaling sel dan ekspresi gen (7). Pada penelitian in vivo telah membuktikan 
bahwa genistein dapat menurunkan produksi gen yang mengekspresikan ACE melalui penghambatan jalur signaling sel (12).

Kandungan senyawa flavonoid bekerja sebagai zat antihipertensi dengan cara mempengaruhi menghambat perubahan angiotensin I menjadi angiotensin II sehingga menghambat pengeluaran Aldosteron oleh ACE. Aldosteron berdampak pada ginjal untuk menahan natrium dan air, lebih banyak air yang dikeluarkan dari tubuh dan tekanan darah akan turun jika aldosteron dihambat produksinya dalam tubuh (13).

\section{c. Kalium}

Kedelai juga mengandung kalium 1469 mg/100 gram dimana kalium bermanfaat untuk diuretik yang mengurangi volume cairan tubuh dan curah jantung, meningkatkan ekskresi natrium, dan air (8). Bahan makanan yang mentah ataupun masih segar banyak mengandung kalium (14).

Kalium menurunkan tekanan darah dengan cara mengatur saraf perifer dan sentral (9). Vaskular bertahan karena dilatasi pembuluh darah dan terjadinya peningkatan jumlah air dan natrium yang hilang. Selain itu, akibat pompa natrium dan kalium dalam tubuh (14).

Konsumsi kalium diatas $200 \mathrm{mg} / \mathrm{hari}$ dapat menurunkan tekanan darah (15). Kalium adalah ion utama di dalam cairan intraseluler. Meningkatnya konsentrasi kalium dalam cairan intraseluler disebabkan oleh banyaknya konsumsi kalium sehingga menarik cairan dari bagian ekstraseluler dan tekanan darah mengalami penurunan (9). Selain itu, manfaat lainnya dapat memicu kerja otot dan simpul saraf, membantu pengiriman oksigen ke otak dan keseimbangan cairan di dalam tubuh (16).

\section{Kesimpulan}

Kandungan susu kedelai dan minuman ekstrak tempe yang berbahan dasar kedelai berdasarkan beberapa penelitian memiliki potensi menurunkan tekanan darah pada penderita hipertensi dengan formulasi dan jumlah yang tepat. Kandungan kacang kedelai yang dapat menurunkan tekanan darah yaitu protein pada kedelai yaitu asam amino arginin dan triptofan yang tinggi, isoflavon, dan kalium. Penelitian ini memiliki kelemahan hanya menjelaskan zat gizi dan zat bioaktif pada minuman berbahan dasar kacang kedelai. Penelitian ini perlu dilakukan lebih lanjut dengan metode eksperimen dengan perbedaan dari peneliti sebelumnya..

\section{Daftar Pustaka}

1. Yulianti I. Pengaruh pemberian Pisang Ambon terhadap Tekanan Darah pada Lansia Penderita Hipertensi. J Ners dan Kebidanan (Journal Ners Midwifery). 2019;6(1):070-6.

2. Apriza Yanti C, Muliati R. Pengaruh Pemberian Jus Semangka Merah dan Kuning Terhadap Tekanan Darah Lansia Menderita Hipertensi. J Endur. 2019;4(2):411.

3. Tirtasari S, Kodim N. Prevalensi dan karakteristik hipertensi pada usia dewasa muda di Indonesia. Tarumanagara Med J. 2019;1 (2):395-402.

4. Chen GC, Chen WH, Tseng KT, Chao PM. The anti-Adiposity effect of bitter melon seed oil is solely attributed to its fatty acid components. Lipids Health Dis. 2017;16(1):1-10.

5. Wang S, Yu M, Zheng X, Dong S. A bayesian network meta-analysis on the efficacy and safety of eighteen targeted drugs or drug combinations for pulmonary arterial hypertension. Drug Deliv [Internet]. 2018;25(1):1898-909. Available from: https://doi.org/10.1080/10717544.2018.1523257

6. Handayani F, Yahya G, Darmawan S, Fayasari A. Darah Pasien Hipertensi Di Rumah Sakit Islam Jakarta. 2017;01(01):19-27.

7. Yulifianti R, Muzaiyanah S, Utomo JS. Kedelai sebagai Bahan Pangan Kaya Isoflavon. Bul Palawija. 2018;16(2):84.

8. Murti DN. Pengaruh Pemberian Susu Kedelai Terhadap Perubahan Tekanan Darah Pada Lansia Dengan Hipertensi Di Karang Tengah Nototirto Gamping Sleman Yogyakarta. Yogyakarta: Universitas 'Aisyiyah Yogyakarta; 2018. p. 15.

9. Ansarullah A, Hardinsyah H, Marliyati SA, Astawan M. Efek Intervensi Minuman Tempe Terhadap Tekanan Darah Pada Penderita Hipertensi Dan Hiperkolesterolemia. J Gizi dan Pangan. 2017;12(2):101-8.

10. Krisnawati A. Soybean as Source of Functional Food. Iptek Tanam Pangan. 2017;12(1):57-65.

11. Zaheer K, Akhtar MH. An Updated Review of Dietary Isoflavones: Nutrition , Processing, Bioavailability and Impacts on Human Health An updated review of dietary iso fl avones : Nutrition, processing, bioavailability and impacts on human health. Crit Rev Food Sci Nutr [nternet]. 2017;0(0):1-14. Available from: http://dx.doi.org/10.1080/10408398.2014.989958 
12. Widiasari S. Mekanisme Inhibisi Angiotensin Converting Enzym oleh Flavonoid pada Hipertensi. Collab Med J. 2018;1(2):30-44.

13. Kusmita DB, Effendy EM, Yulianita. Uji Efektivitas Ekstrak Daun Bangun-Bangun (Coleus amboinicus lour) Sebagai Anti Hipertensi Pada Tikus Sprague-Dawley Yang Di Induksi NaCl. 2018;

14. Polii R, Engka JNA, Sapulete IM. Hubungan kadar natrium dengan tekanan darah pada remaja di Kecamatan Bolangitang Barat Kabupaten Bolaang Mongondow Utara. J e-Biomedik. 2016;4(2):37-45.

15. Afifah AAL. \& DN. of Nutrition, Volume Nomor Tahun 2015, Halaman 365-371 of Nutrition College , College Volume Online di : http://ejournal-s1.undip.ac.id/index.php/jnc. 2015;4:365-71.

16. Susanti MR. Hubungan Asupan Natrium dan Kalium Dengan Tekanan Darah Pada Lansia Di Kelurahan Pajang. 2017; 